IRA-International Journal of Management \& Social Sciences

ISSN 2455-2267; Vol.04, Issue 02 (2016)

Pg. no. 371-375

Institute of Research Advances

http://research-advances.org/index.php/RAJMSS

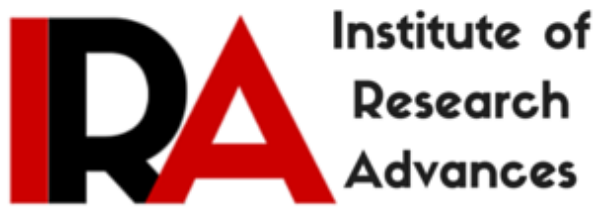

\title{
The Art of Managing Small Business - Interdeco - A Case Study
}

Dr. R. Krishnakumar [B.Sc (Engg)., MBA., M.Phil., PhD., LLB (LLM)]

Professor and Research Program Coordinator,

School Of Management

Dayananada Sagar University, Bangalore, India.

Type of Review: Peer Review

DOI: http://dx.doi.org/10.21013/jmss.v4.n2.p6

\section{How to cite this paper:}

Krishnakumar, R. (2016). The Art of Managing Small Business - Interdeco - A Case Study. IRA-International Journal of Management \& Social Sciences (ISSN 2455-2267), 4(2), 371-375. doi:http://dx.doi.org/10.21013/jmss.v4.n2.p6

(C) Institute of Research Advances

(c) EY-NO

This work is licensed under a Creative Commons Attribution-Non Commercial 4.0 International License subject to proper citation to the publication source of the work.

Disclaimer: The scholarly papers as reviewed and published by the Institute of Research Advances (IRA) are the views and opinions of their respective authors and are not the views or opinions of the IRA. The IRA disclaims of any harm or loss caused due to the published content to any party. 
Ram Shetty started his business in 2005 in a small way which grew up to be a big business. He was into the business of bidding through contracts for nationalised banks to erect ATM structures. His business turnover grew from a humble Rs 20 Lakh to be a $600 \mathrm{Lakh}$ business within a span of 6 years by 2012. Although his business grew he faced a problem which most start ups face. He was having a cash crunch in managing his say to day operations. This is normally an issue of working capital management. Dr Ramesh a consultant was roped in and he was from academia and had done a few consulting projects ,but he was not able to identify the issue and provide a solution to Mr Shetty, although he had recognised that things were not moving in the right direction. Dr Ramesh had been a consultant for the firm for almost three long years. My assistance was sought to probe the whole issue and provide a solution.

Since it was a one man business he hardly had any time to organise and analyse things, I mean the way things were moving. He was assisted by staff of 4 . Two female staffs were managing the office. They were vested with responsibility of receiving the tender documents, preparing the quotations for the tenders, submission of these tenders, managing the accounts, bank. There was one supervisor whose job was to coordinate the work site supervision and execution of work by carpenters. The carpenters were all under job contract the supervisor's role also included movement of material to the work site. There was one van driver who was driving the vehicle in which materials were transported. There was one office assistant coordinated the purchase of materials from hardware suppliers in addition to taking care of the logistics in terms of movement of material to the work site.

Mr Ram believed in an informal structure that drove his business. He was happy and believed that things were moving well. There was no much hierarchy. All were meeting up with Ram and taking directions from him and he felt that this way he had better control over things.

The tenders were received from banks with whom Mr Ram had good contacts and he was liaising with these banks personally meeting the higher ups. The tenders were quoted and most of the time Interdeco was the lowest quote and they were successful in bidding the tender. The material requirement estimates were done based on software that was developed under Mr Ram's guidance as he had rich experience in this field. The material requirement for each job order was then released to the hardware shop for supply of materials. The materials were then in turn received and the inventory was kept in a godown.

Sometimes the carpenters were also working in the godown doing some prefabrication works to be carried over to the work site later. Interdeco was well known for execution of work on time which was very important in this line of business. The challenge Interdeco faced was in terms of getting the job done by the carpenters. Often carpenters took more time than that was estimated this not only pushed costs up but also timely completion of the project was an issue. Interdeco was into complete interiors of the bank like carpentry of the entire office layout of the bank including the cabins and cash counter and the various counters were staff of the bank sit and operate their business.

Understanding the requirements of the bank and operating within the budgets cutting cost was another challenge which Mr Ram faced. He was ably assisted by his wife who sits in the office and monitors the accounts and takes care of the payments in his absence.

Mr Ram had established a system of payments which he thought was foolproof. Only cheques were issued for all purchases made from the hardware suppliers. In case of fuel for the vehicle Interdeco had arrangement with the petrol bunk were in staff were issued tokens form his office mentioning the vehicle number and payments were made to the petrol bunk on a weekly basis directly from the office. Only petty cash of up to Rs 15000 was managed by the two female office staff who made vouchers against payments made and the accounts were checked by Mr Ram whenever he was in the office.

Most of the times Mr. Ram was away from his office as he had to follow up with the pending payments and visit each work site himself to ensure things were in order. The great difficulty Mr ram 
faced was he had works going on in different locations like Andhra, Karnataka and various places in Tamilnadu. So much of his time was spent in travelling around and he was so exhausted. He had to work on issues of material problems, absence of carpenters at times in work site that would affect the timely completion of the work. Of late Mr. Ram because of such a growth in volume of his business was unable to handle all of this and he called in a consultant to help him out in organising his business.

At that point in time the author of this case (consultant) was roped in to analyse the whole issue. Where did it all start? The consultant first had an informal interaction with all the staff and understood the nature of activities each was involved. The consultant also in the second phase perused the accounting vouchers and bills and the whole system of accounting procedures including the inflow of cash and outflow of cash. There were interesting revelations as large number of vouchers were pertaining to advances paid to carpenters for which there was no proper tracking mechanism as the same must be deducted from the payment that were due to them at the end of completion of their job during settlement of their payments.

There were usually some materials in excess in each suite which was lying in the work site after completion of the job, nobody knew what happened to the materials. They should have come back to the stores. No records were available. With regard to the vehicle fuel bills there was no proper tracking mechanism. There were no records as to when the fuel request was raised each time how many kms has the vehicle done and when the last time fuel request was made was and the quantity.

The consultant was faced with a challenge as to where to start. He grafted his person as supervisor at Interdeco. The person was to observe being a part of the team. He was part of the office team for 10 days analysing and observing the cash transactions and sending confidential reports to the consultant. He was also asked to visit the various work sites and report what was happening. The most important advice given to him was at no point in time the staff should have any suspicion. He was also asked to travel in the vehicle and observe the movement of vehicles and refuelling process. He also took physical check on inventory of the stock of all materials in the stock yard and verified the same with stock records.

His findings revealed several things which shocked the consultant and Mr Shetty. The materials in inventory in stock yard did not tally with the records and many materials were not there or there were shortages. The excess materials that were left over on completion of the work at site were sold by the carpenter and he made use of the materials for other works that he executed for some other party and took money from them.Regrading the petty cash there was mismanagement and funds were siphoned off by preparing vouchers showing advances paid to carpenters. The carpenters had an understanding with the office staff and they shared the money. There were few bills pertaining to purchase of materials at the work site which was required at work site. The bills were there and payments made but actual material was not procured. Regarding the refuelling system the drivers took the vouchers from office. But the driver had an understanding with the bunk pump operator. When a voucher for 20 litres of diesel was issued, only 15 litres of diesel was put into the tank. The cash for 5 litres of diesel was split between the driver and pump operator in the bunk. The materials that were supplied by the hardware stores for which payments were made directly only through cheques, so Mr Shetty thought he had a perfect control over the system of purchase. The tracking of the system revealed that bills were raised and part of the material was diverted to another party or sold. The carpenter and supervisor made good money. At times the materials were shown as returns and cash was paid by the hardware shop staff to the carpenters and a share of it was taken by the billing staff in the hardware shop. The purchase of materials was in high volumes and involved significant proportion of the turnover of the company. So at every point at which Mr Shetty thought he had a system for every process the reality was different. These findings were shocking to Mr Shetty.

Mr Shetty was so upset about the whole thing. The total estimated embezzlement amount in his organisation in 3 months time was an estimated at whopping Rs 30 Lakhs by the consultant with records. When each staff was called and the records were shown although initially they resisted 
finally they admitted their involvement .He wanted to handover the staff involved to the police. The consultant advised Mr Shetty to sack all of them and take fresh staff and pay them well, so that they do not steal. Many start ups face similar issues as to what Mr Shetty faced. Understanding the issues of start ups is quite a different game altogether.

1. What are your reactions to this situation? How would you react if you were in the position of Mr Shetty?

2. What is going-on here? What are your inferences from it?

3. What factors influenced the evolution of events?

4. Why did Mr. Shetty decide to have an informal method of reporting?

5. Do you think Mr Shetty could have avoided this situation by taking some proactive measures? Why did he fail to do so?

6. Why the system that was in place failed to work? Could you come out with a better business system?

7. Why do you think it was inappropriate for Mr Shetty to empower people?

8. What does Mr Shetty need to do to achieve his stated goals?

9. How else might he have handled the situation?

10. What immediate action he should take?

11. What general principles and concepts seem to follow from this analysis?

\section{References:}

1. Abanis, T., Sunday, A., Burani, A., and Eliabu, B. (2013) Financial management practices in small and medium enterprises in selected districts in western Uganda, Research Journal of Finance and Accounting 4(2), 29-35.

2. Abdulsaleh, A. M., and Worthington, A.C. (2013) Small and medium-sized enterprises financing: a review of the literature, International Journal of Business and Management 8(4), $36-54$.

3. Amoako, G. K. (2013) Accounting practices of SMEs: A case study of Kumasi Metropolis in Ghana, International Journal of Business and Management 8(24).

4. Belghitar, Y., and Khan, J. (2013) Governance mechanisms, investment opportunity set and SMEs cash holdings, Small Business Economics 40(1), 59-72.

5. Bolton, J. E. (1971) Report of the Committee of Inquiry on Small Firms. London, HMSO.

6. Brinckmann, J., Salomo, S, and Gemuenden, H.G. (2011) Financial management competence of founding teams and growth of new technology based firms, Entrepreneurship Theory and Practice 35(2), 217-243.

7. Enqvist, J., Graham, M., and Nikkinen, J. (2014) The impact of working capital management on firm profitability in different business cycles: Evidence from Finland, Research in International Business and Finance 32(2014), 36-49.

8. Gul, S., Khan, M.B., Rehman, S.U., Kahn, M.T., Khan, M., and Khan, W. (2013) Working capital management and performance of SME sector, European Journal of Business and Management 5(1), 60-68.

9. Mungal, A., and Garbharran, H.L. (2014) The perceptions of small businesses in the implementation of cash management techniques, Journal of Economics and Behavioral Studies 6(1), 75-83.

10. Nunes, P., Gonçalves, M., and Serrasqueiro, Z. (2013) The influence of age on SMEs' growth determinants: empirical evidence, Small Business Economics 40(2), 249-272.

11. Orobia, L. A., Byabashaija, W., Munene, J.C., Sejjaaka, S.K., and Musinguzi, D. (2013) How do small business owners manage working capital in an emerging economy? A qualitative inquiry, Qualitative Research in Accounting \& Management 10(2), 127-143.

12. Solomon, G. T., Bryant, A., May, K., and Perry, V. (2013) Survival of the fittest: Technical assistance, survival and growth of small businesses and implications for public policy, Technovation 33(8/9), 292-301. 
13. Tauringana, V., and Afrifa, G.A. (2013) The relative importance of working capital management and its components to SMEs' profitability, Journal of Small Business and Enterprise Development 20(3), 453-469.

14. Van Auken, H., and Carraher, S. (2013) Influences on frequency of preparation of financial statements among SMEs, Journal of Innovation Management 1(1), 143-157. 